\title{
Diversity of 4-Chloro-2-nitrophenol-Degrading Bacteria in a Waste Water Sample
}

\author{
Pankaj Kumar Arora, ${ }^{1}$ Alok Srivastava, ${ }^{2}$ and Vijay Pal Singh ${ }^{2}$ \\ ${ }^{1}$ School of Biotechnology, Yeungnam University, Gyeongsan 712-749, Republic of Korea \\ ${ }^{2}$ Department of Plant Science, Faculty of Applied Sciences, MJP Rohilkhand University, Bareilly, India \\ Correspondence should be addressed to Vijay Pal Singh; singhvp03@rediffmail.com
}

Received 27 August 2015; Revised 23 December 2015; Accepted 11 January 2016

Academic Editor: Davide Vione

Copyright (c) 2016 Pankaj Kumar Arora et al. This is an open access article distributed under the Creative Commons Attribution License, which permits unrestricted use, distribution, and reproduction in any medium, provided the original work is properly cited.

\begin{abstract}
Eighteen bacterial strains, isolated from a waste water sample collected from a chemically contaminated site, Patancheru ( $17^{\circ} 32^{\prime} \mathrm{N}$ $78^{\circ} 16^{\prime} \mathrm{E} / 17.53^{\circ} \mathrm{N} 78.27^{\circ} \mathrm{E}$ ), India, were able to decolorize 4-chloro-2-nitrophenol (4C2NP) in the presence of an additional carbon source. These eighteen 4C2NP-decolorizing strains have been identified as members of four different genera, including Bacillus, Paenibacillus, Pseudomonas, and Leuconostoc based on the 16S rRNA gene sequencing and phylogenetic analysis. Most of the bacteria (10) belonged to the genus Bacillus and contributed 56\% of the total 4C2NP-degrading bacteria, whereas the members of genera Paenibacillus and Pseudomonas represented $22 \%$ and 17\%, respectively, of total 4C2NP-degrading isolates. There was only one species of Leuconostoc capable of degrading 4C2NP. This is the first report of the diversity of 4C2NP-decolorizing bacteria in a waste water sample. Furthermore, one bacterium, Bacillus aryabhattai strain PC-7, was able to decolorize 4C2NP up to a concentration of $2.0 \mathrm{mM}$. Gas chromatography-mass spectrometry analysis identified 5-chloro-2-methylbenzoxazole as the final product of 4C2NP decolorization in strain PC-7.
\end{abstract}

\section{Introduction}

4-Chloro-2-nitrophenol (4C2NP) is a toxic compound that is widespread in the environment including ground water and soil [1]. Both physiochemical and biological methods have been used for 4C2NP decontamination [1-4]. Biological methods have advantages over physiochemical methods because they are more effective and less expensive. Among biological methods, bacterial remediation is an effective way to remove xenobiotic compounds [1].

Few bacteria capable of utilizing 4C2NP as their sole sources of carbon and energy have been isolated and characterized from a variety of sources $[5,6]$. A 4C2NPmineralizing bacterium, Exiguobacterium sp. PMA, initiates the $4 \mathrm{C} 2 \mathrm{NP}$ degradation with reduction of $4 \mathrm{C} 2 \mathrm{NP}$ into 4-chloro-2-aminophenol that is then dehalogenated to aminophenol with release of chloride ion. Further degradation of aminophenol proceeds via ammonia release [5]. A genetically engineered bacterium, Pseudomonas sp. N31, was also capable of degrading $4 \mathrm{C} 2 \mathrm{NP}$ via chloride and nitrite releases and the formation of 4-chlorocatechol [6]. A mixed culture of Alcaligenes sp. and Enterobacter sp. degraded 4C2NP via 4-chloro-2-aminophenol [7].

Few bacteria biotransformed toxic 4C2NP into other less toxic compounds rather than performing its complete mineralization [8-10]. A marine bacterium, Bacillus sp. MW1 [8], a soil bacterium, Bacillus subtilus RKJ 800 [9], and Pseudomonas sp. JHN [10] decolorized and biotransformed 4C2NP into 5-chloro-2-methylbenzoxazole. In this transformation mechanism, 4-chloro-2-aminophenol and 4-chloro2-acetaminophenol were also detected as metabolites.

The aim of this study is to identify and characterize additional 4C2NP-degrading bacteria. In this communication, we have studied the diversity of 4C2NP-degrading bacteria.

\section{Materials and Methods}

2.1. Isolation of $4 \mathrm{C} 2 \mathrm{NP}$-Degrading Bacteria. Eighteen bacterial strains were isolated from a waste water sample collected from a chemically contaminated site, Patancheru $\left(17^{\circ} 32^{\prime} \mathrm{N}\right.$ 


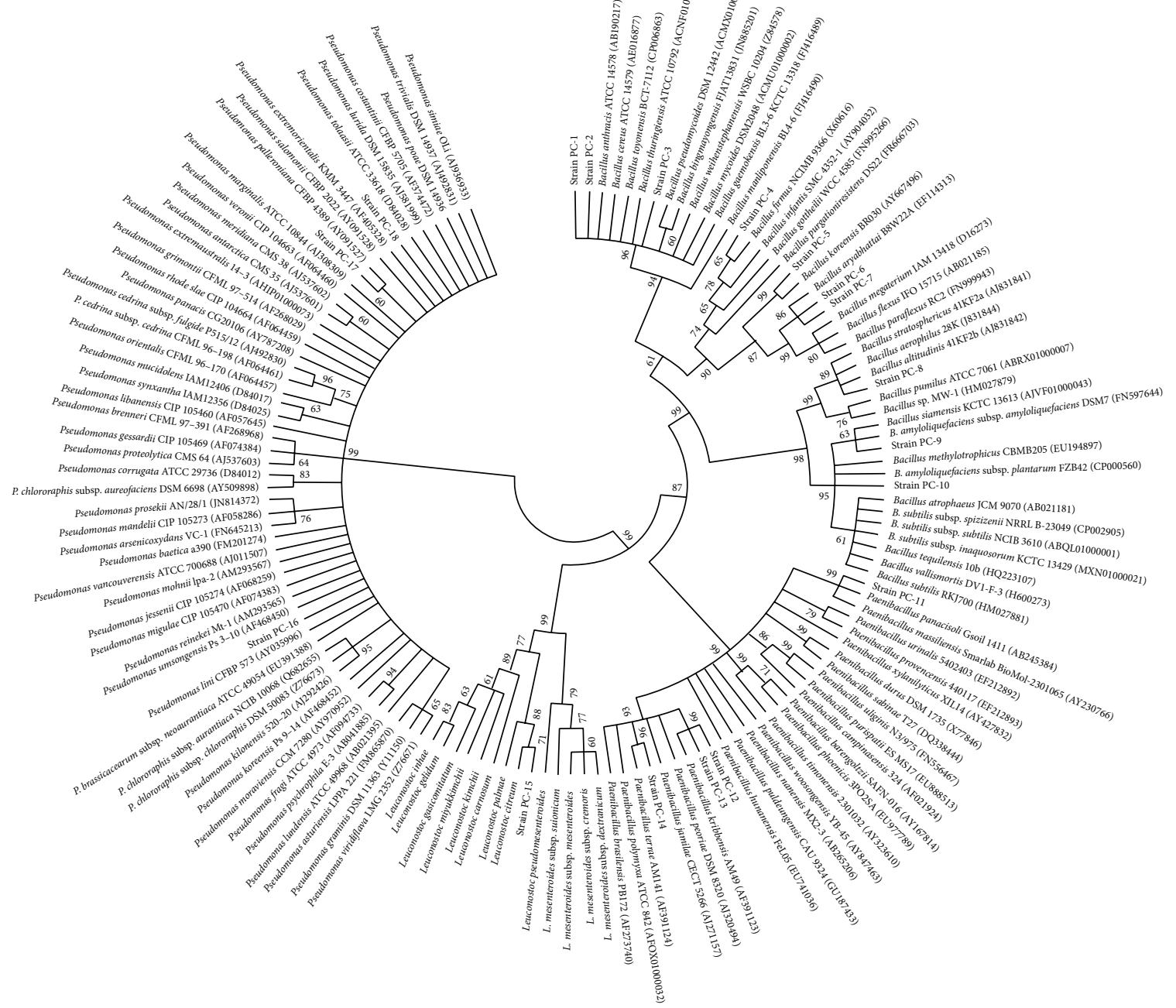

FIGURE 1: Phylogenetic tree of 4-chloro-2-nitrophenol-decolorizing bacteria based on their 16S rRNA genes.

$\left.78^{\circ} 16^{\prime} \mathrm{E} / 17.53^{\circ} \mathrm{N} 78.27^{\circ} \mathrm{E}\right)$, India, by an enrichment method using $4 \mathrm{C} 2 \mathrm{NP}$ as a cosubstrate. Patancheru is the major industrial hub of Andhra Pradesh, India, where several major chemical industries are located. This place has been considered one of the worst polluted places in the world $[11,12]$. The highest level of drug pollution in water was found in Patancheru in 2009 [12]. Researchers have observed measurable quantities of 21 different manufactured drugs in water [12]. This pollution results from waste water dumped into the river by the over 90 local pharmaceutical manufacturers [12].

For enrichment, $1 \mathrm{~mL}$ of the waste water sample was added to a $200 \mathrm{~mL}$ Erlenmeyer flask containing $50 \mathrm{~mL}$ minimal media, $0.5 \mathrm{mM} 4 \mathrm{C} 2 \mathrm{NP}$, and $10 \mathrm{mM}$ glucose. The minimal medium was prepared by dissolving the following compounds in $100 \mathrm{~mL}$ of double distilled water: $0.4 \mathrm{~g} \quad \mathrm{Na}_{2} \mathrm{HPO}_{4}, \quad 0.2 \mathrm{~g} \quad \mathrm{KH}_{2} \mathrm{PO}_{4}, \quad 0.08 \mathrm{~g} \quad \mathrm{NaNO}_{3}, 0.08 \mathrm{~g}$ $\mathrm{MgSO}_{4} \cdot 7 \mathrm{H}_{2} \mathrm{O}, 0.1 \mathrm{~mL}$ trace element solution, and $1.8 \mathrm{~g}$ agar [5]. One liter of the trace element solution contained $0.10 \mathrm{~g} \mathrm{Al}(\mathrm{OH})_{3}, 0.05 \mathrm{~g} \mathrm{SnCl}_{2} \cdot 2 \mathrm{H}_{2} \mathrm{O}, 0.05 \mathrm{~g} \mathrm{KI}, 0.05 \mathrm{~g} \mathrm{LiCl}$, $0.08 \mathrm{~g} \mathrm{MgSO}_{4}, 0.05 \mathrm{~g} \mathrm{H}_{3} \mathrm{BO}_{3}, 0.10 \mathrm{~g} \mathrm{ZnSO}_{4} \cdot 7 \mathrm{H}_{2} \mathrm{O}, 0.01 \mathrm{~g}$ $\mathrm{CoCl}_{2}, 0.01 \mathrm{~g} \mathrm{NiSO}_{4} \cdot 6 \mathrm{H}_{2} \mathrm{O}, 0.05 \mathrm{~g} \mathrm{BaCl}_{2}$, and $0.05 \mathrm{~g}_{\left(\mathrm{NH}_{4}\right)_{6}}$
$\mathrm{Mo}_{7} \mathrm{O}_{24} \cdot 4 \mathrm{H}_{2} \mathrm{O}$ [5]. The enrichment flask was incubated at $30^{\circ} \mathrm{C}$ under shaking conditions at $200 \mathrm{rpm}$. Upon decolorization of the yellow color of 4C2NP in the flask, the culture was serially diluted and plated on minimal agar plates containing $0.5 \mathrm{mM} 4 \mathrm{C} 2 \mathrm{NP}$ and $10 \mathrm{mM}$ glucose. Eighteen different morphotypes were grown on the plates containing 4C2NP and $10 \mathrm{mM}$ glucose. Eighteen colonies showed decolorization around them suggesting that these bacteria have the ability to utilize 4C2NP. These colonies were streaked further on nutrient agar plate to check the purity and pure cultures were used to monitor their ability to degrade $4 \mathrm{C} 2 \mathrm{NP}$ at higher concentrations (from 0.5 to $2.5 \mathrm{mM})$.

2.2. Identification of 4-Chloro-2-nitrophenol-Decolorizing Bacteria and Phylogenetic Analysis. All 4C2NP-decolorizing bacteria were identified on the basis of $16 \mathrm{~S}$ rRNA gene sequencing using the universal primers $27 \mathrm{f}$ and $1492 \mathrm{r}$ as described previously $[13,14]$. The $16 \mathrm{~S}$ rRNA gene sequences of related strains were retrieved from the NCBI and aligned using the ClusterW program. A phylogenetic tree was 
TABLE 1: Showing degradation of various concentrations of 4-chloro-2-nitrophenol by the eighteen bacteria.

\begin{tabular}{|c|c|c|c|c|}
\hline Serial number & Strain & $\begin{array}{l}\text { Proposed bacterial name based on } \\
\text { the } 16 \mathrm{~S} \text { rRNA gene sequencing }\end{array}$ & Isolation source & $\begin{array}{c}\text { The 4C2NP concentration where } \\
\text { strain can be completely } \\
\text { transformed }\end{array}$ \\
\hline 1 & Strain PC-1 & Bacillus cereus & Contaminated soil & $1.0 \mathrm{mM}$ \\
\hline 2 & Strain PC-2 & Bacillus toyonensis & Contaminated soil & $0.9 \mathrm{mM}$ \\
\hline 3 & Strain PC-3 & Bacillus thuringiensis & Contaminated soil & $1.0 \mathrm{mM}$ \\
\hline 4 & Strain PC-4 & Bacillus firmus & Contaminated soil & $0.8 \mathrm{mM}$ \\
\hline 5 & Strain PC-5 & Bacillus koreensis & Contaminated soil & $0.6 \mathrm{mM}$ \\
\hline 6 & Strain PC-6 & Bacillus megaterium & Contaminated soil & $1.5 \mathrm{mM}$ \\
\hline 7 & Strain PC-7 & Bacillus aryabhattai & Contaminated soil & $2.0 \mathrm{mM}$ \\
\hline 8 & Strain PC-8 & Bacillus aerophilus & Contaminated soil & $0.6 \mathrm{mM}$ \\
\hline 9 & Strain PC-9 & Bacillus siamensis & Contaminated soil & $0.8 \mathrm{mM}$ \\
\hline 10 & Strain PC-10 & Bacillus amyloliquefaciens & Contaminated soil & $0.9 \mathrm{mM}$ \\
\hline 11 & Strain PC-11 & Paenibacillus massiliensis & Contaminated soil & $0.7 \mathrm{mM}$ \\
\hline 12 & Strain PC-12 & Paenibacillus kribensis & Contaminated soil & $0.6 \mathrm{mM}$ \\
\hline 13 & Strain PC-13 & Paenibacillus kribensis & Contaminated soil & $0.5 \mathrm{mM}$ \\
\hline 14 & Strain PC-14 & Paenibacillus terrae & Contaminated soil & $0.5 \mathrm{mM}$ \\
\hline 15 & Strain PC-15 & Leuconostoc citreum & Contaminated soil & $0.5 \mathrm{mM}$ \\
\hline 16 & Strain PC-16 & Pseudomonas lini & Contaminated soil & $0.8 \mathrm{mM}$ \\
\hline 17 & Strain PC-17 & Pseudomonas palleroniana & Contaminated soil & $0.9 \mathrm{mM}$ \\
\hline 18 & Strain PC-18 & Pseudomonas extremorientalis & Contaminated soil & $0.6 \mathrm{mM}$ \\
\hline
\end{tabular}

constructed using the neighbour-joining method as implemented in MEGA $[13,14]$.

2.3. Growth and Decolorization Studies. Bacterial growth was measured in $250 \mathrm{~mL}$ minimal medium containing $10 \mathrm{mM}$ glucose and various concentrations of $4 \mathrm{C} 2 \mathrm{NP}(0.5$, $1.0,1.5,2.0$, and $2.5 \mathrm{mM}$ ). At every $2 \mathrm{~h}, 3 \mathrm{~mL}$ samples were collected; $1 \mathrm{~mL}$ sample was used for measuring the growth at $600 \mathrm{~nm}$ using a spectrophotometer; another $2 \mathrm{~mL}$ sample was centrifuged and the supernatant was used to monitor the 4C2NP decolorization as well as chloride, ammonia, and nitrite release. The 4C2NP decolorization was measured as the decrease in the optical density at $400 \mathrm{~nm}$ and the $\%$ decolorization was calculated as described previously [8-10]. The chloride, nitrite, and ammonia ions were monitored as described previously [5].

2.4. Identification of Metabolites. Bacterial strains were grown on minimal media containing $10 \mathrm{mM}$ glucose and $2.0 \mathrm{mM} 4 \mathrm{C} 2 \mathrm{NP}$; samples were collected at regular intervals and extracted with ethyl acetate and the extracted samples were analyzed by gas chromatography-mass spectrometry using an Agilent Gas Chromatography system equipped with Time-of-Flight Mass Spectrometer and HP-5 column as described previously [10]. Helium was used as carrier gas at $1.5 \mathrm{~mL} / \mathrm{min}$. The initial column temperature was held at $50^{\circ} \mathrm{C}$ for $1 \mathrm{~min}$ and then temperature was increased at $25^{\circ} / \mathrm{min}$ to $290^{\circ} \mathrm{C}$ and held for $10 \mathrm{~min}$. The samples $(1 \mu \mathrm{L})$ were injected in splitless mode. The temperatures of the transfer line and ion source (electron ionisation mode, $\mathrm{EI}, 70 \mathrm{eV}$ ) were $225^{\circ} \mathrm{C}$ and $250^{\circ} \mathrm{C}$, respectively.

\section{Results and Discussion}

Eighteen bacterial strains, isolated from a chemically contaminated waste water sample collected from Patancheru, decolorized 4C2NP in the presence of glucose. The analysis of the 16S rRNA gene sequences of these strains showed that 10 bacterial strains designated as strain PC-1 to PC-10 belonged to the genus Bacillus whereas 4 bacterial stains, designated as strain PC-11 to PC-14, belonged to the genus Paenibacillus. Strain PC-16, strain PC-17, and strain PC-18 belonged to genus Pseudomonas and strain PC-15 to the genus Leuconostoc.

Results of the 16S rRNA gene sequencing of all eighteen strains were also supported by phylogenetic analysis. Phylogenetic analysis of all eighteen strains with closely related species showed that these strains are distinct to each other and belong to four different genera, that is, Bacillus, Pseudomonas, Paenibacillus, and Leuconostoc (Figure 1).

Figure 2 represents the diversity of 4C2NP-degrading bacteria among these eighteen strains. It was observed that Bacillus spp. are dominant for decolorization of 4C2NP and contributed $56 \%$ of the total 4C2NP-degrading bacteria, whereas Paenibacillus spp. and Pseudomonas spp. represented $22 \%$ and $17 \%$, respectively, of total 4 C2NP-degrading bacteria. There was only one species of Leuconostoc capable of degrading $4 \mathrm{C} 2 \mathrm{NP}$, representing $5.0 \%$ of the diversity.

We have also investigated decolorization of $4 \mathrm{C} 2 \mathrm{NP}$ at various concentrations by these eighteen strains and the results are summarized in Table 1 . They showed that Bacillus aryabhattai strain PC-7 was able to decolorize 4C2NP up to $2.0 \mathrm{mM}$ concentration. This strain was selected for detailed study. 


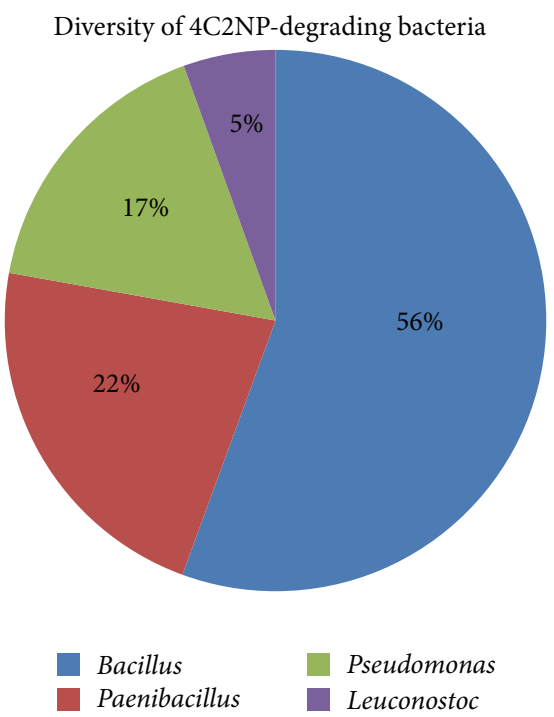

FIGURE 2: Diversity of 4-chloro-2-nitrophenol-decolorizing bacteria.

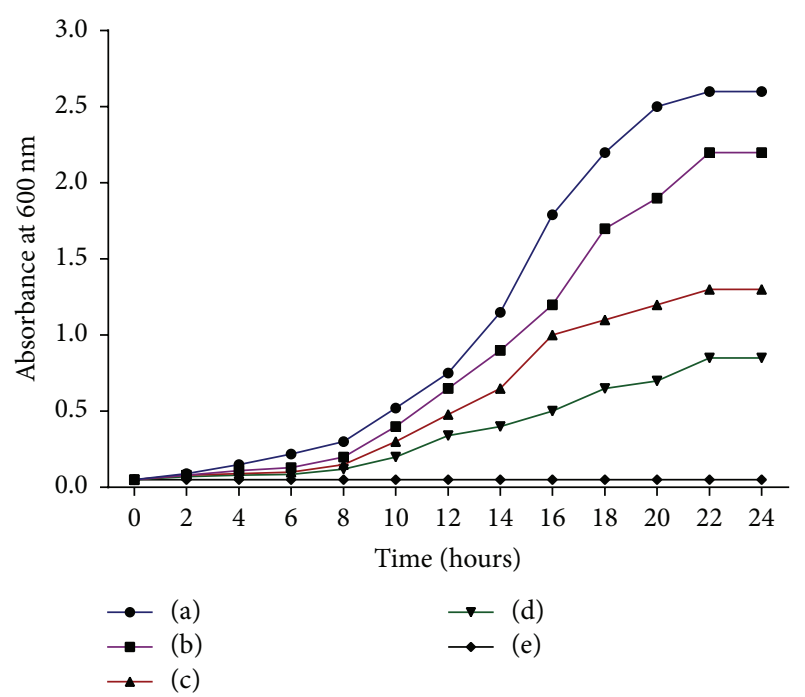

FIGURE 3: Growth of Bacillus aryabhattai strain PC-7 on minimal medium containing $10 \mathrm{mM}$ glucose and (a) $0.5 \mathrm{mM} 4$-chloro-2nitrophenol, (b) $1.0 \mathrm{mM}$ 4-chloro-2-nitrophenol, (c) $1.5 \mathrm{mM} \mathrm{4-}$ chloro-2-nitrophenol, (d) $2.0 \mathrm{mM}$ 4-chloro-2-nitrophenol, and (e) $2.5 \mathrm{mM}$ 4-chloro-2-nitrophenol.

Bacillus aryabhattai strain PC-7 was grown in minimal medium containing $10 \mathrm{mM}$ glucose in the presence of different concentration of $4 \mathrm{C} 2 \mathrm{NP}(0.5,1.0,1.5,2.0$, and $2.5 \mathrm{mM})$. As the $4 \mathrm{C} 2 \mathrm{NP}$ concentration was increased, the growth of strain PC-7 was decreased. There was no growth with $2.5 \mathrm{mM} 4 \mathrm{C} 2 \mathrm{NP}$. The optimum growth was observed at the concentration of $0.5 \mathrm{mM}$, whereas minimum growth was observed at $2.0 \mathrm{mM}$ concentration (Figure 3). The 4C2NP decolorization was also monitored at various concentrations and it was observed that strain PC-7 decolorized $0.5 \mathrm{mM}$ $4 \mathrm{C} 2 \mathrm{NP}$ very quickly (in only 12 hours), whereas it took $24 \mathrm{~h}$ to decolorize the $2.0 \mathrm{mM}$ concentration (Figure 4 ). There was

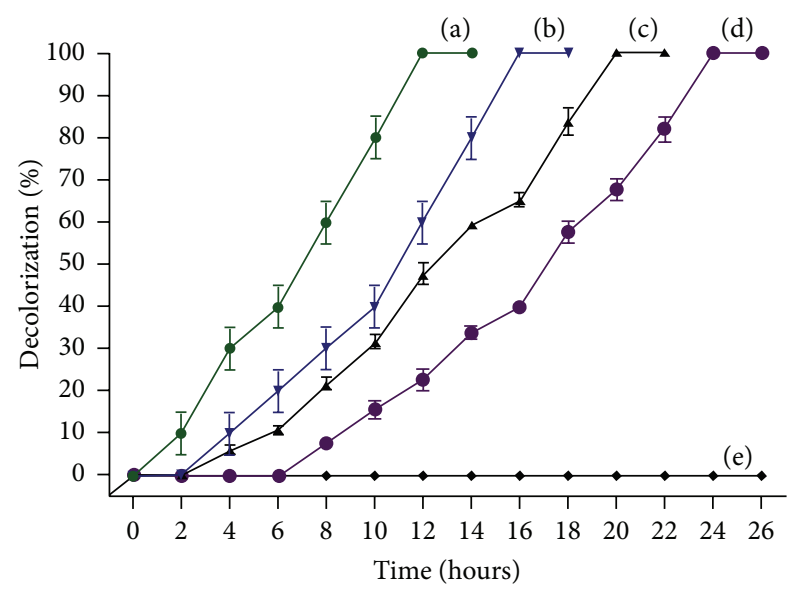

Figure 4: Decolorization of 4-chloro-2-nitrophenol by Bacillus aryabhattai strain PC-7. (a) $0.5 \mathrm{mM}$ 4-chloro-2-nitrophenol, (b) $1.0 \mathrm{mM}$ 4-chloro-2-nitrophenol, (c) $1.5 \mathrm{mM} 4$-chloro-2-nitrophenol, (d) $2.0 \mathrm{mM}$ 4-chloro-2-nitrophenol, and (e) $2.5 \mathrm{mM}$ 4-chloro-2nitrophenol.

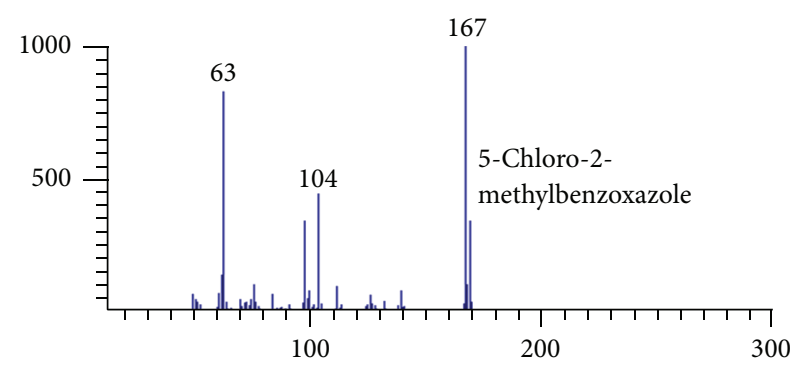

FIGURE 5: Mass spectrum of the decolorized product of 4-chloro-2nitrophenol by Bacillus aryabhattai strain PC-7.

no decolorization at the concentration of $2.5 \mathrm{mM}$ because strain PC-7 was unable to grow in these conditions.

GC-MS was carried out to identify the product of 4C2NP decolorization. The mass spectrum of the final metabolite contains a molecular ion peak at $m / z 167$ and other fragments are observed at $m / z 104$ and $m / z 63$ (Figure 5). On the basis of NIST library search, this product showed $92.4 \%$ similarity between its mass spectrum and the mass spectrum of 5-chloro-2-methylbenzoxazole. To date, few bacteria are known to degrade 4C2NP, which include Bacillus sp. MW1 [8], Bacillus subtilis RKJ 700 [9], Pseudomonas sp. JHN [10], Pseudomonas sp. N31 [6], Exiguobacterium sp. PMA [5], and a mixed culture of Alcaligenes sp. and Enterobacter sp. [7]. In this study, we have characterized eighteen bacterial strains isolated from a contaminated water sample of India that are able to degrade $4 \mathrm{C} 2 \mathrm{NP}$. These bacteria belong to four different genera including Pseudomonas, Bacillus, Leuconostoc, and Paenibacillus and they decolorized 4C2NP only in the presence of an additional carbon source. All eighteen bacterial strains were able to decolorize 4C2NP up to various concentrations. Previous studies showed that Bacillus sp. MW-1 was able to degrade $4 \mathrm{C} 2 \mathrm{NP}$ at the concentration of $0.3 \mathrm{mM}$ [8]; Pseudomonas sp. JHN was able to decolorize $0.5 \mathrm{mM}$ concentration [10] and strain RKJ 700 was 


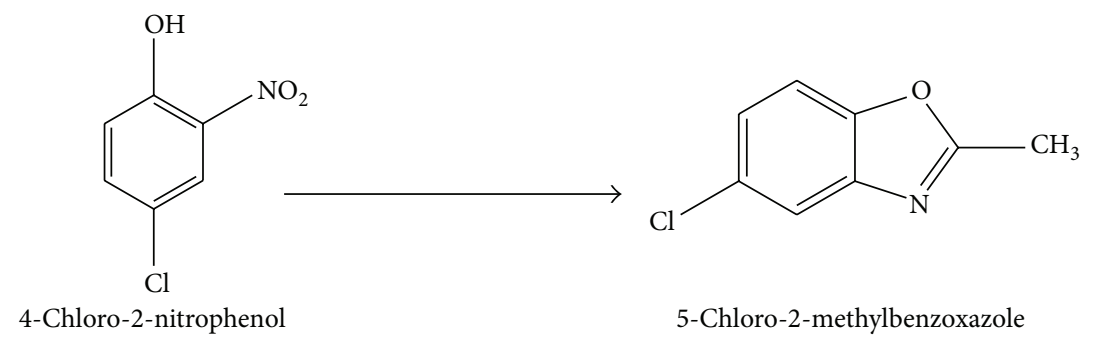

FIGURE 6: Biotransformation of 4-chloro-2-nitrophenol to 5-chloro-2-methylbenzoxazole.

able to decolorize the concentration of $1.5 \mathrm{mM}$ [9]. In this study, Bacillus aryabhattai strain PC-7 was able to decolorize $4 \mathrm{C} 2 \mathrm{NP}$ up to $2.0 \mathrm{mM}$ (the highest concentration reached thus far).

Bacterial degradation of 4C2NP proceeds via either mineralization or biotransformation. Few bacteria mineralized 4C2NP completely without requirement of any additional carbon source [5]. Exiguobacterium sp. PMA mineralized 4C2NP via 4-chloroaminophenol and aminophenol [5]. The $4 \mathrm{C} 2 \mathrm{NP}$ biotransformation involves the conversion of $4 \mathrm{C} 2 \mathrm{NP}$ into nontoxic compounds via detoxification. Bacillus sp. MW- 1 and B. subtilis RKJ 700 biotransformed 4C2NP into 5-chloro-2-methylbenzoxazole. In this study, Bacillus aryabhattai strain PC-7 also biotransformed 4C2NP into 5-chloro2-methylbenzoxazole (Figure 6). However, strain PC-7 was able to decolorize a high concentration of 4C2NP that was not previously reported for any bacterial strain.

\section{Conclusion}

Eighteen bacterial strains belonging to four different genera, including Bacillus, Paenibacillus, Pseudomonas, and Leuconostoc, decolorized 4C2NP in the presence of glucose. Bacillus aryabhattai PC-7 is an efficient degrader and decolorized $4 \mathrm{C} 2 \mathrm{NP}$ up to $2.0 \mathrm{mM}$ concentrations. 5-Chloro-2methylbenzoxazole was identified as the final product of the 4C2NP decolorization.

\section{Conflict of Interests}

The authors declare that there is no conflict of interests regarding the publication of this paper.

\section{References}

[1] P. K. Arora, C. Sasikala, and C. V. Ramana, "Degradation of chlorinated nitroaromatic compounds," Applied Microbiology and Biotechnology, vol. 93, no. 6, pp. 2265-2277, 2012.

[2] A. Mehrizad, M. Aghaie, P. Gharbani, S. Dastmalchi, M. Monajjemi, and K. Zare, "Comparison of 4-chloro-2-nitrophenol adsorption on single-walled and multi-walled carbon nanotubes," Iranian Journal of Environmental Health Science and Engineering, vol. 9, article 5, 2012.

[3] P. Gharbani, M. Khosravi, S. M. Tabatabaii, K. Zare, S. Dastmalchi, and A. Mehrizad, "Degradation of trace aqueous 4chloro-2-nitrophenol occurring in pharmaceutical industrial wastewater by ozone," International Journal of Environmental Science and Technology, vol. 7, no. 2, pp. 377-384, 2010.

[4] S. Adami and A. Fakhri, "Adsorption of 4-chloro-2-nitrophenol by zero valent iron nanoparticles and Pd-doped zero valent iron nanoparticles surfaces: isotherm, kinetic and mechanism modeling," Journal of Physical Chemistry and Biophysic, vol. 3, p. 115, 2013.

[5] P. K. Arora, A. Sharma, R. Mehta, B. D. Shenoy, A. Srivastava, and V. P. Singh, "Metabolism of 4-chloro-2-nitrophenol in a Gram-positive bacterium, Exiguobacterium sp. PMA," Microbial Cell Factories, vol. 11, article 150, 2012.

[6] C. Bruhn, R. C. Bayly, and H.-J. Knackmuss, "The in vivo construction of 4-chloro-2-nitrophenol assimilatory bacteria," Archives of Microbiology, vol. 150, no. 2, pp. 171-177, 1988.

[7] J. Beunink and H.-J. Rehm, "Coupled reductive and oxidative degradation of 4-chloro-2-nitrophenol by a co-immobilized mixed culture system," Applied Microbiology and Biotechnology, vol. 34, no. 1, pp. 108-115, 1990.

[8] P. K. Arora and R. K. Jain, "Biotransformation of 4-chloro2-nitrophenol into 5-chloro-2-methylbenzoxazole by a marine Bacillus sp. strain MW-1," Biodegradation, vol. 23, no. 2, pp. 325331, 2012

[9] P. K. Arora, "Decolourization of 4-chloro-2-nitrophenol by a soil bacterium, Bacillus subtilis RKJ 700," PLoS ONE, vol. 7, no. 12, Article ID e52012, 2012.

[10] P. K. Arora and H. Bae, "Biotransformation and chemotaxis of 4-chloro-2-nitrophenol by Pseudomonas sp. JHN," Microbial Cell Factories, vol. 13, no. 1, article 110, 2014.

[11] D. G. J. Larsson, C. de Pedro, and N. Paxéus, "Effluent from drug manufactures contains extremely high levels of pharmaceuticals," Journal of Hazardous Materials, vol. 148, no. 3, pp. 751-755, 2007.

[12] J. Fick, H. Söderström, R. H. Lindberg, C. Phan, M. Tysklind, and D. G. J. Larsson, "Contamination of surface, ground, and drinking water from pharmaceutical production," Environmental Toxicology and Chemistry, vol. 28, no. 12, pp. 2522-2527, 2009.

[13] P. K. Arora, "Staphylococcus lipolyticus sp. nov., a new coldadapted lipase producing marine species," Annals of Microbiology, vol. 63, no. 3, pp. 913-922, 2013.

[14] P. K. Arora and R. K. Jain, “Arthrobacter nitrophenolicus sp. nov. a new 2-chloro-4-nitrophenol degrading bacterium isolated from contaminated soil," 3 Biotech, vol. 3, no. 1, pp. 29-32, 2013. 

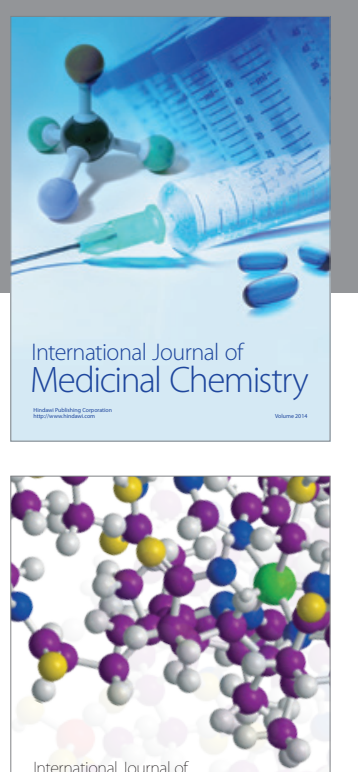

Carbohydrate Chemistry

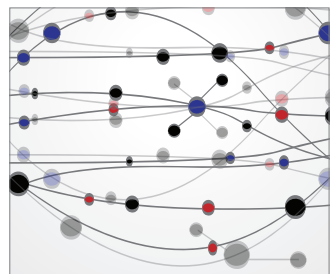

The Scientific World Journal
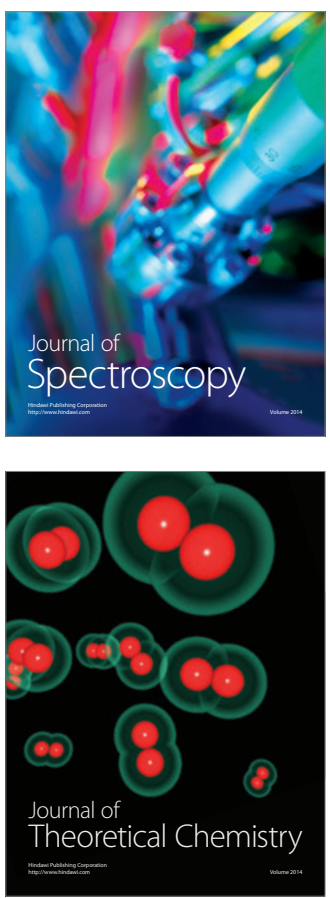
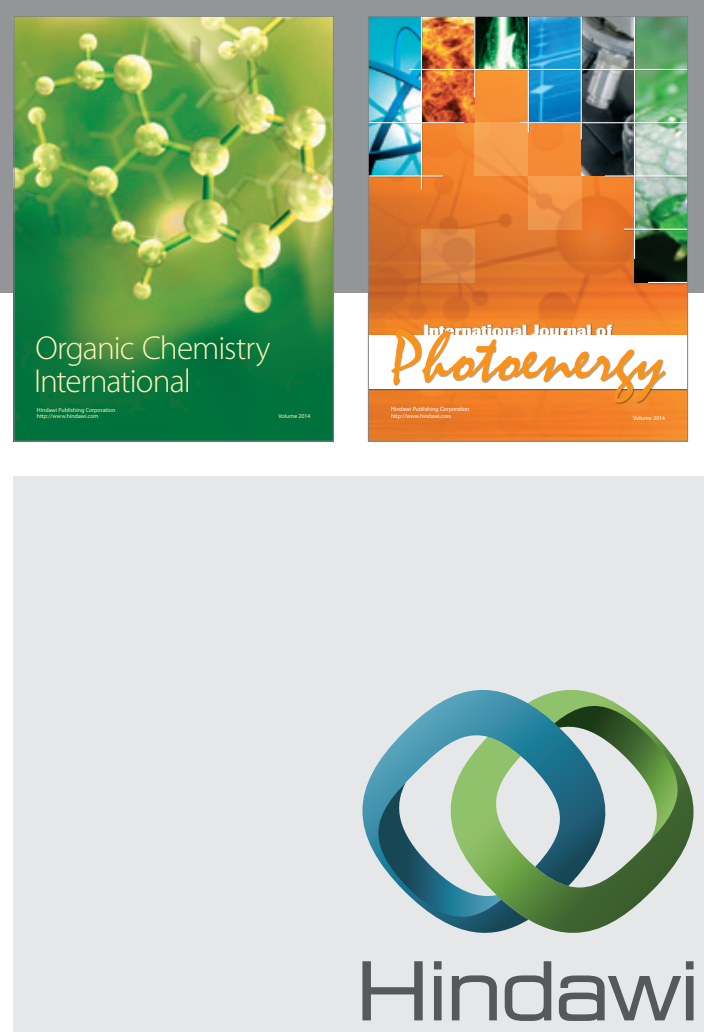

Submit your manuscripts at

http://www.hindawi.com

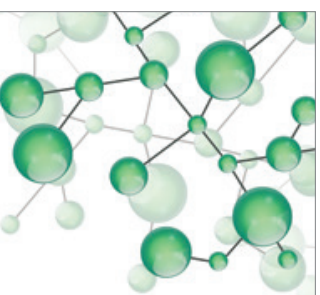

International Journal of

Inorganic Chemistry

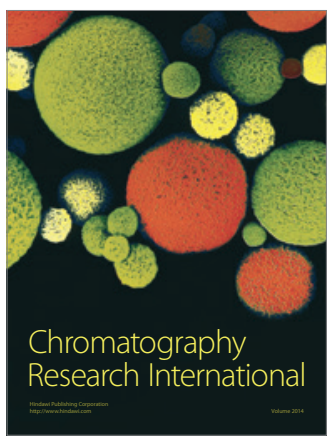

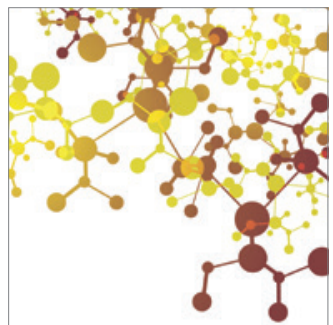

Applied Chemistry
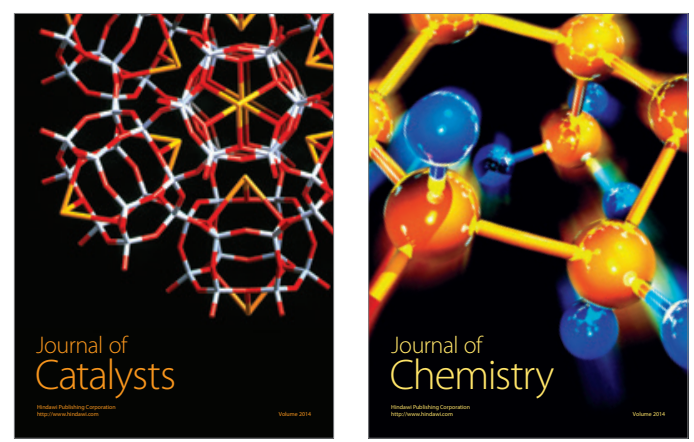
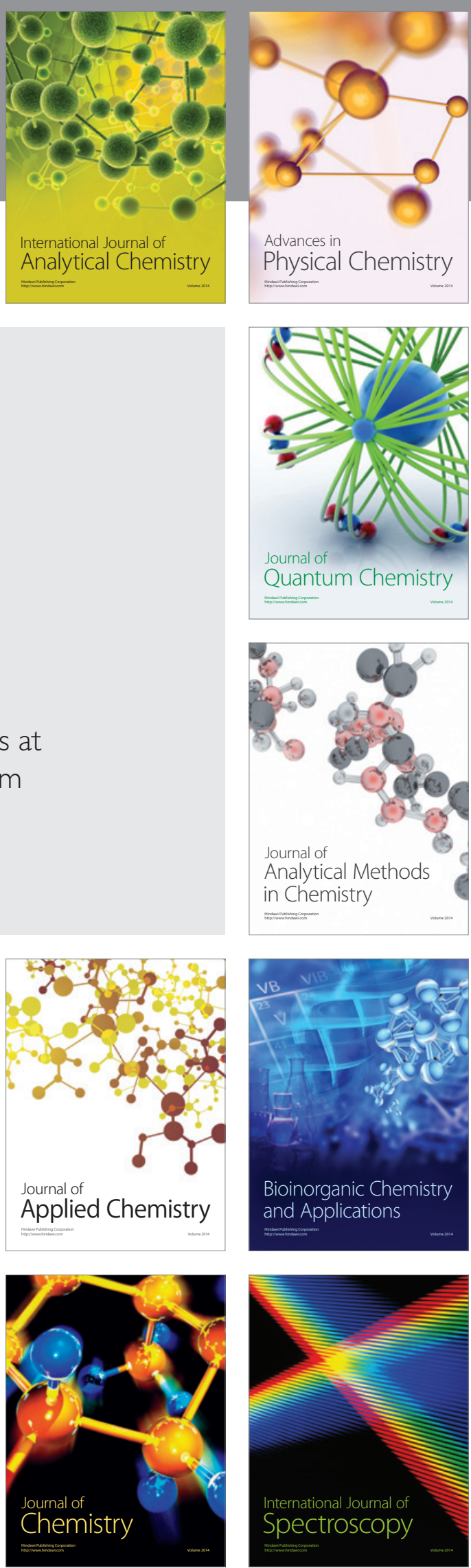